\title{
Front Matter: Volume 8569
}

, "Front Matter: Volume 8569," Proc. SPIE 8569, Mechanisms for Low-Light Therapy VIII, 856901 (22 March 2013); doi: 10.1117/12.2022391

SPIE. Event: SPIE BiOS, 2013, San Francisco, California, United States 


\title{
PROGRESS IN BIOMEDICAL OPTICS AND IMAGING
}

\section{Mechanisms for Low-Light Therapy VIII}

\author{
Michael R. Hamblin \\ Praveen R. Arany \\ James D. Carroll \\ Editors
}

2 February 2013

San Francisco, California, United States

Sponsored and Published by

SPIE 
The papers included in this volume were part of the technical conference cited on the cover and title page. Papers were selected and subject to review by the editors and conference program committee. Some conference presentations may not be available for publication. The papers published in these proceedings reflect the work and thoughts of the authors and are published herein as submitted. The publisher is not responsible for the validity of the information or for any outcomes resulting from reliance thereon.

Please use the following format to cite material from this book:

Author(s), "Title of Paper," in Mechanisms for Low-Light Therapy VIII, edited by Michael R. Hamblin, Praveen R. Arany, James D. Carroll, Proceedings of SPIE Vol. 8569 (SPIE, Bellingham, WA, 2013) Article CID Number.

ISSN: $1605-7422$

ISBN: 9780819493385

Published by

SPIE

P.O. Box 10, Bellingham, Washington 98227-0010 USA

Telephone +1 3606763290 (Pacific Time) · Fax +1 3606471445

SPIE.org

Copyright (C) 2013, Society of Photo-Optical Instrumentation Engineers.

Copying of material in this book for internal or personal use, or for the internal or personal use of specific clients, beyond the fair use provisions granted by the U.S. Copyright Law is authorized by SPIE subject to payment of copying fees. The Transactional Reporting Service base fee for this volume is $\$ 18.00$ per article (or portion thereof), which should be paid directly to the Copyright Clearance Center (CCC), 222 Rosewood Drive, Danvers, MA 01923. Payment may also be made electronically through CCC Online at copyright.com. Other copying for republication, resale, advertising or promotion, or any form of systematic or multiple reproduction of any material in this book is prohibited except with permission in writing from the publisher. The CCC fee code is $1605-7422 / 13 / \$ 18.00$.

Printed in the United States of America.

Publication of record for individual papers is online in the SPIE Digital Library.

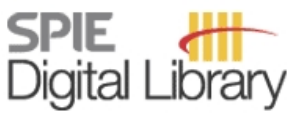

SPIEDigitallibrary.org

Paper Numbering: Proceedings of SPIE follow an e-First publication model, with papers published first online and then in print and on CD-ROM. Papers are published as they are submitted and meet publication criteria. A unique, consistent, permanent citation identifier (CID) number is assigned to each article at the time of the first publication. Utilization of CIDs allows articles to be fully citable as soon as they are published online, and connects the same identifier to all online, print, and electronic versions of the publication. SPIE uses a six-digit CID article numbering system in which:

- The first four digits correspond to the SPIE volume number.

- The last two digits indicate publication order within the volume using a Base 36 numbering

system employing both numerals and letters. These two-number sets start with 00, 01, 02, 03, 04, $05,06,07,08,09,0 A, 0 B \ldots 0 Z$, followed by 10-1Z, 20-2Z, etc.

The CID Number appears on each page of the manuscript. The complete citation is used on the first page, and an abbreviated version on subsequent pages. Numbers in the index correspond to the last two digits of the six-digit CID Number. 


\title{
Contents
}

\author{
vii Conference Committee
}

\section{SESSION 1 DOSIMETRY}

856905 Inhomogeneity in optical properties of rat brain: a study for LLLT dosimetry [8569-4]

M. V. P. Sousa, Univ. de São Paulo (Brazil); R. Prates, I. T. Kato, C. P. Sabino, T. M. Yoshimura,

L. C. Suzuki, Instituto de Pesquisas Energéticas e Nucleares (Brazil); A. C. Magalhães,

E. M. Yoshimura, Univ. de São Paulo (Brazil); M. S. Ribeiro, Instituto de Pesquisas Energéticas

e Nucleares (Brazil)

856906 Red and infrared light distribution in blood [8569-5]

A. C. de Magalhães, E. M. Yoshimura, Univ. de São Paulo (Brazil)

\section{SESSION $2 \quad$ IN VITRO STUDIES}

856907 Tissue regeneration with photobiomodulation [8569-28]

E. G. Tang, P. R. Arany, National Institute of Dental and Craniofacial Research (United States)

856908 Exposing human retinal pigmented epithelial cells to red light in vitro elicits an adaptive response to a subsequent 2- $\mu \mathrm{m}$ laser challenge [8569-7]

K. J. Schuster, TASC, Inc. (United States); L. E. Estlack, Conceptual MindWorks, Inc. (United States); J. C. Wigle, Air Force Research Lab. (United States)

856909 How low-level laser therapy can change mechanical properties of cells [8569-8] A. C. de Magalhães, Univ. de São Paulo (Brazil); D. Martinez, Univ. de São Paulo Medical School (Brazil); M. J. Ferreira, Univ. Estadual de Campinas (Brazil); E. M. Yoshimura, A. M. Alencar, M. C. Chavantes, Univ. de São Paulo (Brazil)

8569 OA Study on the Curcumin dynamics and distribution through living biofilms [8569-9] M. T. Carvalho, Univ. de São Paulo (Brazil); L. N. Dovigo, A. S. Rastelli, Univ. Estadual Paulista (Brazil); V. S. Bagnato, Univ. de São Paulo (Brazil)

\section{SESSION $3 \quad$ IN VIVO STUDIES}

8569 OC Effects of speckle-like laser irradiation on growth of bacteria in vitro [8569-11]

A. Yu. Popov, N. A. Popova, A. V. Tyurin, Odessa I.I. Mechnikov National Univ. (Ukraine);

V. Grimblatov, Photonics Life Technologies Lab. (United States)

8569 OD Biostimulative effect of 809-nm diode laser and indocyanine green on p.aeruginosa instead of photodynamic therapy (Invited Paper) [8569-12]

N. Aysan, N. Topaloglu, S. Yuksel, M. Gulsoy, Bogaziçi Üniv. (Turkey) 
8569 OE Transcranial low-level light therapy produces neuroprotection, neurogenesis and BDNF after TBI in mice (Invited Paper) [8569-13]

F. Vatansever, Wellman Ctr. for Photomedicine (United States) and Harvard Medical School (United States); W. Xuan, Wellman Ctr. for Photomedicine (United States) and Harvard Medical School (United States) and Taditional Chinese Medical Univ. of Guangxi (China); Y. Huang, Wellman Ctr. for Photomedicine (United States) and Harvard Medical School (United States) and Guangxi Medical Univ. (China); M. R. Hamblin, Wellman Ctr. for Photomedicine (United States) and Harvard Medical School (United States) and HarvardMIT Division of Health Sciences and Technology (United States)

\section{SESSION $4 \quad$ IN VIVO/CLINICAL STUDIES}

8569 OF Photobiomodulation reduces photoreceptor death and regulates cytoprotection in early states of P23H retinal dystrophy [8569-14]

D. K. Kirk, Australian National Univ. (Australia); S. Gopalakrishnan, H. Schmitt, B. Abroe, The Univ. of Wisconsin-Milwaukee (United States); M. Stoehr, A. Dubis, J. Carroll, Medical College of Wisconsin (United States); J. Stone, The Univ. of Sydney (Australia); K. Valter, Australian National Univ. (Australia); J. Eells, The Univ. of Wisconsin-Milwaukee (United States)

$8569 \mathrm{OJ}$ Influence of wavelength on the outcome of the treatment of TMJ disorders: TMDS [8569-18] A. L. B. Pinheiro, Univ. Federal da Bahia (Brazil) and Camilo Castelo Branco Univ. (Brazil) and Nacional Institute of Optics and Photonics (Brazil); A. M. C. Marques, Univ. Federal da Bahia (Brazil) and National Institute of Optics and Photonics (Brazil); C. M. Carvalho, M. C. T. Cangussú, Univ. Federal da Bahia (Brazil); L. G. P. Soares, Univ. Federal da Bahia (Brazil) and National Institute of Optics and Photonics (Brazil)

\section{POSTER SESSION}

$8569 \mathrm{OL}$ Raman study of the effect of LED light on grafted bone defects [8569-20]

L. G. P. Soares, Federal Univ. of Bahia (Brazil) and Nacional Institute of Optics and Photonics (Brazil); J. M. S. Aciole, G. T. S. Aciole, A. F. S. Barbosa, Federal Univ. of Bahia (Brazill); L. Silveira-Júnior, Nacional Institute of Optics and Photonics (Brazil); A. L. B. Pinheiro, Federal Univ. of Bahia (Brazil) and Nacional Institute of Optics and Photonics (Brazil) and Camilo Castelo Branco Univ. (Brazil)

8569 OM Green LED associated to $20 \%$ hydrogen peroxide for dental bleaching: nanomorfologic study of enamel by scanning electron microscopy [8569-21]

S. C.P. S. Oliveira, Univ. Federal da Bahia (Brazil) and National Institute of Optics and Photonics (Brazil); G. M. P. Santos, Gonçalo Muniz Institute (Brazil); J. S. C. Monteiro, F. J. P. Sampaio, M. F. M. Gesteira, Univ. Federal da Bahia (Brazil) and National Institute of Optics and Photonics (Brazil); F. A. A. Zanin, Univ. Federal da Bahia (Brazil) and National Institute of Optics and Photonics (Brazil) and Brugnera \& Zanin Institute (Brazil);

M. A. V. Santos, Gonçalo Muniz Institute (Brazil); A. L. B. Pinheiro, Univ. Federal da Bahia (Brazil) and National Institute of Optics and Photonics (Brazil) and Brugnera \& Zanin Institute (Brazil) and Camilo Castelo Branco Univ. (Brazil) 
8569 ON In vitro study of the photodynamic antimicrobial therapy (PACT) against promastigotes form of the leishmania (viannia) braziliensis: in vitro study [8569-22]

A. F. S. Barbosa, Univ. Federal de Pernambuco (Brazil) and Research Ctr. Gonçalo Moniz (Brazil) and Univ. Federal da Bahia (Brazil); B. B. Sangiorgi, Research Ctr. Gonçalo Moniz (Brazil); S. L. Galdino, I. R. Pitta, Univ. Federal de Pernambuco (Brazil); M. Barral-Netto, Centro de Pesquisa Gonçalo Moniz (Brazil); A. L. B. Pinheiro, Univ. Federal da Bahia (Brazil) and Univ. of São Paulo (Brazil) and Camilo Castelo Branco Univ. (Brazil)

856900 Use of laser photomodulation in the evolution of oral mucositis associated to cyclophosphamide, methotrexate, 5-fluouracil - CMF in 5 fluouracil + adriamycin + cyclophosphamide - FAC chemotherapy protocols in patients with breast cancer [8569-23] M. de Fátima Lima Ferreira, Federal Univ. of Alagoas (Brazil) and Univ. Federal da Bahia (Brazil); F. B. de Carvalho, Univ. Federal da Bahia (Brazil); S. C. P. S. de Oliveira, J. S. C. Monteiro, Univ. Federal da Bahia (Brazil) and National Institute of Optics and Photonics (Brazil); G. M. P. Santos, Gonçalo Muniz Institute (Brazil); M. F. M. Gesteira, Univ. Federal da Bahia (Brazil) and National Institute of Optics and Photonics (Brazil); T. C. T. Maia, Federal Univ. of Alagoas (Brazil); A. L. B. Pinheiro, Univ. Federal da Bahia (Brazil) and National Institute of Optics and Photonics (Brazil) and Camilo Castelo Branco Univ. (Brazil)

8569 OP Photodynamic antimicrobial chemotherapy (PACT) using phenothiazines derivatives associated with the red laser against staphylococcus aureus [8569-24]

S. C. P. S. Oliveira, Univ. Federal da Bahia (Brazil) and National Institute of Optics and Photonics (Brazil); G. M. P. Santos, Gonçalo Muniz Institute (Brazil); J. S. C. Monteiro, Univ. Federal da Bahia (Brazil) and National Institute of Optics and Photonics (Brazil);

A. F. S. Miranda, Gonçalo Muniz Institute (Brazil); F. J. P. Sampaio, M. F. M. Gesteira, Univ. Federal da Bahia (Brazil) and National Institute of Optics and Photonics (Brazil); F. A. A. Zanin, Univ. Federal da Bahia (Brazil) and Brugnera \& Zanin Institute (Brazil); M. A. V. Santos, Gonçalo Muniz Institute (Brazil); A. L. B. Pinheiro, Univ. Federal da Bahia (Brazil)

$85690 Q$ The response of human retinal pigmented epithelial cells in vitro to changes in nitric oxide concentration stimulated by low levels of red light [8569-25]

B. J. Lavey, Air Force Research Lab. (United States); L. E. Estlack, Conceptual MindWorks, Inc. (United States); K. J. Schuster, TASC, Inc. (United States); B. A. Rockwell, J. C. Wigle, Air Force Research Lab. (United States)

8569 OR Photodynamic antimicrobial chemotherapy (PACT) using phenothiazines derivatives associated with the red-orange LED against staphylococcus aureus [8569-26]

J. S. C. Monteiro, S. C. P. S. Oliveira, Univ. Federal da Bahia (Brazil) and National Institute of Optics and Photonics (Brazil); G. M. P. Santos, A. F. S. Miranda, Gonçalo Muniz Institute (Brazil); F. J. P. Sampaio, M. F. M. Gesteira, Univ. Federal da Bahia (Brazil) and National Institute of Optics and Photonics (Brazil); F. A. A. Zainn, Univ. Federal da Bahia (Brazil) and Brugnera \& Zanin Institute (Brazil); M. A. V. Santos, Gonçalo Muniz Institute (Brazil); A. L. B. Pinheiro, Univ. Federal da Bahia (Brazil) and National Institute of Optics and Photonics (Brazil) and Brugnera \& Zanin Institute (Brazil) and Camilo Castelo Branco Univ. (Brazil)

Author Index 
Proc. of SPIE Vol. $8569856901-6$

Downloaded From: https://www.spiedigitallibrary.org/conference-proceedings-of-spie on 26 Apr 2023 Terms of Use: https://www.spiedigitallibrary.org/terms-of-use 


\title{
Conference Committee
}

\author{
Symposium Chairs
}

James Fujimoto, Massachusetts Institute of Technology (United States)

R. Rox Anderson, Wellman Center for Photomedicine, Massachusetts General Hospital (United States) and Harvard School of Medicine (United States)

Program Track Chair

Brian Jet-Fei Wong, Beckman Laser Institute and Medical Clinic (United States)

Conference Chairs

Michael R. Hamblin, Wellman Center for Photomedicine (United States)

Praveen R. Arany, National Institute of Dental and Craniofacial Research (United States)

James D. Carroll, THOR Photomedicine Ltd. (United Kingdom)

Conference Program Committee

Tomas Hode, Immunophotonics, Inc. (United States)

Praveen R. Arany, Massachusetts General Hospital (United States)

Daniel Barolet M.D., McGill University (Canada)

Session Chairs

1 Dosimetry

Michael R. Hamblin, Wellman Center for Photomedicine (United States)

2 In vitro Studies

Praveen R. Arany, National Institute of Dental and Craniofacial Research (United States)

3 In vivo Studies

James D. Carroll, THOR Photomedicine Ltd. (United Kingdom)

4 In vivo/Clinical Studies

Tomas Hode, Immunophotonics, Inc. (United States) 
Proc. of SPIE Vol. $8569856901-8$

Downloaded From: https://www.spiedigitallibrary.org/conference-proceedings-of-spie on 26 Apr 2023 Terms of Use: https://www.spiedigitallibrary.org/terms-of-use 